\title{
SEXUALITY AND THE LANGUAGE OF TRANSCENDENCE
}

\author{
HaROLd AsPiz
}

THE ROMANTICS GENERALLY BELIEVED that poetry originates in ecstasy and is a manifestation of the universal creative urge. Whitman's unique contribution to this Romantic premise is his exploration of sexuality as a concomitant and an analogue of spiritual transcendence. Whitman perceived both sexuality and poetry as creative acts that express human love, the higher consciousness, and the search for the primal Word that can unlock the world's mystery. As the poems reach for an epiphany, for holiness, the Whitman persona's ascension into the mystic, transcendent state seems to be launched by the springboard of the tensioned physical senses. Holiness, as one critic points out, "is always something ecstatic ... an intimation that the senses report too little, that something ought to order our lives, according to an apprehension of perfect harmony, unity, etc."1 And as Agnieszka Salska observes, "seen as a progression toward a moment of contact, an illumination, or reconciliation, [Whitman's] poems resemble religious meditations as they strive to attain a state of grace, though grace may come in shockingly secular guises - as sexual (even homosexual) union or as a political vision of perfect domesticity. The visionary climax of a Whitman poem," she adds, "constitutes the structural climax as well."2

Inborn in each person, Whitman seems to say, coexist the sexual urge and the urge to transcend. These two ennobling urges nurture one another; the mightiest sexual drives lead the persona to an intimation of the transcendent state. But one way of interpreting Whitman's sexual utterances is that the two states - sexual and spiritual elevation - may not be equal. Sexuality in Whitman's poems is not usually an end in itself, for the sexual state is anterior to and generally less sustained than the transcendent state. In fact, most depictions of sexual arousal in Leaves of Grass are structured to culminate in a state of spiritual and visionary elevation.

Sexuality in Leaves of Grass is expressed as a nexus of metaphors - verbal constructs related to the persona's craving for transcendence. Inasmuch as metaphors are generally capable of being translated into other metaphors, ${ }^{3}$ Whitman's sexual and transcendental utterances often form sets of interacting and interchangeable constructs. To Whitman, sexuality is an essential element in his role as poet, a "maker," or "vates." "The Vates," he noted, "were priests and physiologists.") 4 The persona portrays a maker in both senses of that word: a horny maker/begetter of a new world vision, if not of a new world, and a vatic, creative maker/poet who seeks the primal Word to interpret it and to confer a gift of it on mankind. These roles involve the classical patterns of transcendence: intense passion, irrationality, and insights into 
the divinity of the most diverse phenomena. Both sexual exaltation and spiritual transcendence partake of what Louis Zukofsky has called the essential "fire and light Power" of the creative process. ${ }^{5}$

Most of Whitman's sexual utterances, in the poems, form part of an elaborate pattern in which the fleshly, sexual passion is transcended or merged into the sublime or spiritual. His language of sexuality becomes involved in his language of transcendence in two ways: first, the "public" language addressed to his readers and the "En-Masse" as part of a eugenics-related program for the purification of a new, perfected race, and second, the selfdramatizing utterance of the Whitman persona as a sexually charged mystic creator and speaker who replicates the rapturous state of primal creation in language that is animistic, totemic, ritualistic, and symbolic.

Whitman's public language is not inconsistent with a transcendentalist view which strabismically focused one eye on the North Star and the other on some glittering reformist cause. As I have pointed out elsewhere, an array of American reformers and scientists in Whitman's day believed that the new eugenics-programmed marriage and programmed parenting, often including the sort of earth-shaking copulations and rapturous sex idealized in "A Woman Waits for Me," "I Sing the Body Electric," and "Song of the Broad-Axe"-could help usher in the millennium. ${ }^{6}$ In these poems and in some of his self-written anonymous reviews, Whitman idealizes the persona in terms of the eugenic ideal as the champion American breeder to be matched with prize female stock. As the ideological mainstay of phrenology, whose lore was so important to Whitman's development, the new eugenics was a chief source of the public stance toward sexuality in Whitman's poems. The public Whitman, whose Democratic Vistas proclaims that "parentage must consider itself in advance,"7 depicted the marriage bed, with its athletic copulations between splendidly matched specimens, as a launching pad for a new breed of spiritualized Americans. "Spontaneous Me" praises "the great chastity of paternity to match the great chastity of maternity." Like John Humphrey Noyes, the much-scandalized leader of the Oneida Community and the Perfectionists, who resided in Brooklyn during the formative years of Leaves of Grass (1849-1854), ${ }^{8}$ the public Whitman sought to inculcate a spiritually centered sexual self-control and to establish new, purer sexual mores as initiatory steps toward a new spiritual order. The Adamic Whitman persona in the early editions of Leaves of Grass - "Lusty, phallic, with potent original loins, perfectly sweet" ("Ages and Ages Returning at Intervals")-is a vigorous, horny, fatherly, pedagogical, and spiritual being who refracts much of the ideology and language of sexual reform, which mingled the physically superb, the pleasurable, and the mystical. Even the sexual ecstasy depicted in the poems mirrors the reformists' notion that sexual ecstasy is eugenically desirable and, ultimately, spiritual.

In terms of the poems' elements of mystic sexuality, it need not matter, of course, whether the implied sexual acts are heterosexual, homosexual, mas- 
turbatory, or the free play of the persona's sexual fantasy. Those expressions of sexuality which operate outside heterosexual contexts are equally analogues of the Whitman persona's universal, spiritual love and his transcendent craving. The "adhesive" love of the "Calamus" poems, as Clayton Eshelman points out, involves a blending of the sexual and the spiritual-beyond sex itself. ${ }^{9}$ Similarly, Whitman requires his readers to interpret the imagery of masturbation or of sexual fantasy as expressed in "The Sleepers," "Native Moments," parts of "Song of Myself," and "Spontaneous Me" as manifestations, or analogues, of the same transcendent reaching for mystical experience inherent in the heterosexual sexual/creative act. (The "masturbation of the brain" is what Horatio Greenough had called Emerson's creative process.) $)^{10}$ "Spontaneous Me," that Dionysian hymn to the persona's autoerotic sexual arousal, may be read as a totemic act in which the persona bestows the reader with his "bunch"-a term suggesting both a poetic bouquet or garland and the persona's phallus, the ultimate totem of his inexhaustible creativity. In this poem and others, the persona's sexual and mystic penetration of nature itself, his mingling with, and his insemination of, nature are rituals of transcendence.

A brief canvass of the references of sexuality in "Song of Myself" confirms that the poem's sexual episodes are generally juxtaposed to, and integral with, episodes of transcendence. From the outset - "I celebrate myself, and sing myself"- the poem lays down the theme of transcendence, of the persona's participation in the universal divinity, of his desire to "possess the origin of all poems." Enraptured by his "luscious" masculine self, and meditating on the "electrical" and "procreant urge of the world," the persona experiences his first epiphany as he beds down with God, "the hugging and loving bed-fellow," who secretly bestows on him the bread of life. After singing a hymn of praise to his "I am," his spiritual essence, the persona records his sexually charged union with his spiritual self, or with some spiritual element of the oversoul, one "transparent summer morning" as the "I am" settled its "head athwart my hips and gently turn'd over upon me, / And parted the shirt from my bosom-bone, and plunged your tongue to my bare-stript heart, / And reach'd till you felt my beard, and reach'd till you held my feet." Significantly, this erotic experience is followed by the persona's transcendent awareness of "the peace and knowledge that pass all the argument of the earth," his first inkling of a clue to the universe ("a kelson of the creation is love"), his discovery of divinity in places great and small, and his first intimation of the word or symbol, in Section 6, that may serve to unlock the mystery ("A child said What is the grass?"). He is now launched into the astonishing series of visions of city and country-visions that would be inaccessible to anyone untouched by the divine afflatus-climaxed by the massive kaleidoscopic catalogue of sights and sounds of Section 15.

The middle sections of "Song of Myself" exhibit a series of sexual arousals by which the persona transcends further and becomes more pro- 
foundly visionary. He becomes as one of the gods, reading the souls of women and men, and is aware of his divine selfhood. As the first stage of his transcendence was marked by his having been presented with the bread of life by his divine bed-fellow, so the second stage is marked by the bread-of-life imagery (Section 19) in which the persona sits like a guest at God's table:

This is the meal equally set, this is the meat for natural hunger.

Like an Emersonian hero, the persona beholds emblems everywhere and accepts his duty to interpret them for the world:

To me the converging objects of the universe perpetually flow, All are written to me, and I must get what the writing means.

To catapult him into a still higher transcendent state for greater visionary excursions, the persona undergoes the most astonishing sexual experiences in the entire poem: his titanic matings with the female earth and the female sea and the empyrean universe. These passages are analogues to the striking moments in Sections 14 and 15 of "By Blue Ontario's Shore" in which the nationalistic and superhuman persona seemingly copulates with the personified North American continent-with the entire geographic entity-in order to beget the wished-for breed of superb domestic heroes. (It must have been passages like these that moved Emerson to remark in 1857, in a lovely Victorian euphemism, on "Our wild Whitman, with real imagination but choked by Titanic abdomen."11 Abdomen indeed!) With lyrical intensity, Section 21 of "Song of Myself" suggests that by coupling as an equal with the "voluptuous cool-breath'd earth" ("Thruster holding me tight and that I hold tight! / We hurt each other as the bridegroom and bride hurt each other") 12 and by being cushioned and lulled by the sea ("Dash me with amorous wet, I can repay you") the persona has become "integral" - that is Whitman's word - with the sea and the earth and has acquired a cosmic force of his own. And in Section 24 his spermatic essence becomes a striking metaphor for his transcendence and for the potential transcendence of the "many long dumb voices" as his phallic self ejects heavenward the "threads that connect the stars - and of wombs and of the father-stuff"-that is, the persona's semen. Doting on himself and on his marvelous universe, he exclaims:

Something I cannot see puts upward libidinous prongs, Seas of bright juice suffuse heaven.

And with these spermatic "prongs," the semen that contemporary scientists claimed was the most refined distillation of the brain, the spinal cortex, and the soul, the persona takes hold of heaven, stains the white radiance of eternity with his own sexual/spiritual being. 
By his superhuman copulation with, and his ritual impregnation of, the earth, the sea, and the stars, the persona has ritually become equal to nature. And as repayment for his caresses nature has granted him the prizes of vision, language, and wisdom. Now he can read the laws of nature and can perceive the dialectical balance in the universe; now he can speak "the pass-word primeval," that is, the divine word from the beginning of time. He has become transcendentally lucid. "Speech," he declares in Section 25, "is the twin of my vision."

The persona's transcendent flight is triggered by other sexual stimuli. Listening to the world's sounds, he hears "the train'd soprano" whose voice (in the 1855 version) "convulses me like the climax of my love-grip."13 Exploring the world of "Blind loving wrestling touch, sheath'd, hooded sharptooth'd touch!" the persona soon beholds (in Section 29):

Sprouts take and accumulate, stand by the curb prolific and vital, Landscapes projected masculine, full-sized and golden.

Those vital "sprouts," the product of his own spermatic essence, or his spermatic imagination, may be interpreted, in terms of Whitman's public voice, as the idealized poetic race who will inhabit the golden landscapes of the future, unified by the "omnific" lesson of love, or, more abstractly, as the persona's poetic utterances-his own creative/spermatic essence translated into words.

Intensely stimulated, the persona launches into the most sustained stretch of lyrical, visionary, and transcendent poetry in all of Leaves of Grass. In the final third of the poem, he confirms the universal emblem ("I believe a leaf of grass is no less than the journey-work of the stars"); he radiates emblems, seeing the phenomena of the universe as "emblems of myself"; he transcends space, time, and causality in the massive catalogues of Section 33, where he is "afoot with my vision," the co-sufferer of all who have died or agonized; he is the healer of bodies and souls, who resurrects corpses; and, superbly, he is the "replenish'd" superman. He is the "friendly and flowing savage" whose electrical "emanations" manifest his divine power, the divinity who, like a patriarchal god, is "This day . . . jetting the stuff of far more arrogant republics"-countless numbers of those "prolific and vital" sprouts produced by his divine spermatic self. After "outbidding" all the gods of the past and "Accepting the rough deific sketches to fill out better in myself," in Section 40, he proclaims his inexorable transcendence, in suggestive physiological terms, as a sublime begetter and inseminator of the latent female lifeforce, swearing a fearsome oath upon his "life-lumps!"-the spermatic core of his masculine being:

... waiting my time to be one of the supremes,

The day getting ready for me when I shall do as much good

as the best, and be as prodigious,

By my life-lumps! becoming already a creator,

Putting myself here and now to the ambush'd womb of the shadows. ${ }^{14}$ 
It is worth recapitulating here that the persona's partners in the heroic copulations in "Song of Myself" have been the earth, the sea, the heavens, and that mysterious, seemingly disembodied, archetypal shadowy womb rather than any discernibly real women or men, however abstract or idealized. As a godlike creature, the persona is surely free to choose his sexual partners. Yet the choice of such vague and exalted lovers highlights the symbolic and metaphorical quality of the ostensible sex acts and underscores the hypothesis that the poem's awesome drama of sex is in essence a drama of spiritual transcendence.

In this most exalted state, the Christ-like persona offers the bread of life to the blind (those "with dimes on eyes walking") and to those who never attend "the feast." He continues his upward journey on the stairs leading to the godhead. And as he is nearly suffocated by his lover-disciples, we are made aware that we are in the presence of a god who has mastered "the best of time and space, and who was never measured and never will be measured," and who now confers the bread of life in his own divine right ("Sit awhile, dear son, / Here are biscuits to eat and here is milk to drink"). No longer is he a Daniel who has to "get what the writing means": he is one who finds "letters from God dropt in the street," and recognizes that "every one is sign'd by God's name."

The poem's final epiphany brings the persona to us as a disembodied spirit in the air and beneath our footsoles. In the hauntingly proto-Roethkean harrowing of hell in Section 49, he undergoes the ultimate experience. Couched between two sexually charged French words - "accoucheur" (the term by which many professional obstetricians in Whitman's day preferred to be called) and "debouch" (with its suggestions of both verbal utterance and birthing) - the persona descends into the primal ooze and undergoes the entire cycle of death, decay, and spiritual rebirth. "Unless the individual survives the mutation of matter" and thus achieves immortality, said Whitman's friend Daniel G. Brinton, "the universe is pointless." 15

If the ultimate quest of the transcendentalists was to decipher and reveal the sensory and supersensory emblems of the universe and to survive "the mutation of matter," surely Whitman's triumphant and sexually charged persona succeeds in doing so and shows that the universe is not purposeless. And his quest has succeeded, in large measure, because of his essential sexuality and his capacity for sexual ecstasy.

California State University, Long Beach 


\section{NOTES}

1 Bernard Avishai, "Sacred and Secular," The Nation, 13 April 1985, 434.

2 Agnieszka Salska, Walt Whitman and Emily Dickinson: Poetry of the Central Consciousness (Philadelphia: University of Pennsylvania Press, 1985), 115.

3 Karsten Harris, “The Many Uses of Metaphor," Critical History, 5 (Autumn 1978), 170171 .

4 Whitman, Notebooks and Unpublished Prose Manuscripts, ed. Edward F. Grier (New York: New York University Press, 1984), 5:1899.

5 "Reading and Talking," in The Voice That is Great Within Us: American Poetry of the Twentieth Century, ed. Hayden Carruth (New York: Bantam, 1971), 253.

6 Harold Aspiz, Walt Whitman and the Body Beautiful (Urbana: University of Illinois Press, 1980), 183-209. Excellent sources on nineteenth-century sexual reformism are Taylor Stoehr's Free Love in America: A Documentary History (New York: AMS Press, 1979), and Hal D. Sears's The Sex Radicals: Free Love in High Victorian America (Lawrence: The Regents Press of Kansas, 1977).

7 In Prose Works 1892, ed. Floyd Stovall (New York: New York University Press, 1964), 2:397.

8 Lawrence Foster, Religion and Sexuality: Three American Communal Experiments of the Nineteenth Century (New York: Oxford University Press, 1981), 108.

9 Cited in Scott Giantvalley, "Recent Whitman Studies and Homosexuality," The Cabiron and Gay Books Bulletin, no. 12 (Spring/Summer, 1985), 16.

10 Erik Ingvar Thurin, Emerson as Priest of Pan: A Study in the Metaphysics of Sex (Lawrence: The Regents Press of Kansas, 1981), 205-206.

11 Letters of Ralph Waldo Emerson, ed. Ralph Rusk (New York: Columbia University Press, 1939), 5:87.

12 Leaves of Grass: A Facsimile of the First Edition (San Francisco: Chandler, 1968), 27.

13 Facsimile, 32.

14 The "ambush'd womb" is confusing. Of course, Whitman may simply have meant hidden. But "ambush'd" generally implies hidden (in the woods) to spring an assault - the wrong word in this context. He may have intended something like "embouch'd," by analogy with "embouchure" (Section 49), meaning the entry of a river to the sea-a suggestive sexual image. The poet who twice called a Tibetan priest a "llama" was not linguistically infallible.

15 Brinton in Walt Whitman Fellowship Papers, 3 (May 1897), 34 (verso of a numbered sheet). 